\title{
PENGARUH KREATIVITAS DAN INTERAKSI GURU DALAM PEMBELAJARAN TERHADAP MINAT BELAJAR SISWA DI MASA PANDEMI COVID-19 DI SMKN 2 KURIPAN TAHUN PELAJARAN 2020/2021
}

\author{
Ahmad Muslim ${ }^{1}$ Nadya Restu Amanda ${ }^{2}$ Muhammad Iqbal $^{3}$ \\ Administrasi Pendidikan, FIPP, Universitas Pendidikan Mandalika \\ ahmadmuslim82@ikipmataram.ac.idnadyarestuamanda99@gmail.com \\ empu.inst@yahoo.com
}

\begin{abstract}
Abstrak: Penelitian ini bertujuan mengetahui bagaimana pengaruh kreativitas dan interaksi guru dalam pembelajaran terhadap minat belajar siswa di masa pandemi covid-19 di SMKN 2 Kuripan Tahun Pelajaran 2020/2021. Metode penelitian yang digunakan oleh peneliti adalah 1) sampel yang digunakan dalam penelitian ini adalah 100 siswa sehingga merupakan penelitian study sampel, 2) metode pengumpulan data yang digunakan yaitu metode angket dan dokumentasi, selanjutnya 3) teknik analisis data yang digunakan adalah statistik deskriptif dan analisis regresi ganda dengan bantuan program SPSS 16. Berdasarkan hasil analisis data diperoleh bahwa: 1) Terdapat pengaruh positif kreativitas guru dalam pembelajaran terhadap minat belajar siswa di masa pandemi covid-19, dibuktikan dengan taraf signifikansi kreativitas guru $\left(\mathrm{X}_{1}\right) 0,000<0.05$, dan nilai thitung 3,805 lebih besar dari tabel 1.984 . 2) Terdapat pengaruh interaksi guru dalam pembelajaran terhadap minat belajar siswa di masa pandemi covid-19 dengan taraf signifikansi interaksi guru $\left(\mathrm{X}_{2}\right) 0,008<0.05$, dan nilai $t_{\text {hitung }} 2,719$ lebih besar dari tabel 1.984 . 3) Terdapat pengaruh kreativitas dan interaksi guru dalam pembelajaran terhadap minat belajar siswa di masa pandemi covid-19 dengan nilai $\mathrm{F}_{\text {hitung }}$ sebesar 15,213 dengan nilai $F_{\text {tabel }}$ adalah 3,09 sehingga nilai $F_{\text {hitung }}>F_{\text {tabel }}$ atau dengan taraf signifikansi 0,000 $<0,05$. Berdasarkan hasil analisis tersebut, maka semua Ha diterima. Dengan demikian dapat disimpulkan bahwa $\mathrm{X}_{1}$ dan $\mathrm{X}_{2}$ berpengaruh signifikan baik secara parsial maupun secara simultan terhadap Y atau dengan kata lain ada Pengaruh Kreativitas dan Interaksi Guru dalam Pembelajaran Terhadap Minat Belajar Siswa di Masa Pandemi Covid-19 di SMKN 2 Kuripan Tahun Pelajaran 2020/2021.
\end{abstract}

\section{Kata Kunci: Kreativitas Guru, Minat Belajar Siswa}

\begin{abstract}
This study aimsat determine how the teacher creativity and interaction in learning effects on student interest in learning during the Covid-19 pandemic at State Vocational High School 2 KuripanAcademic Year 2020/2021. The research method used by the researcher was 1) the sample used in this study was 100 students, 2) the data collection method used was the questionnaire and documentation method, then 3) the data analysis technique used was descriptive statistics and multiple regression analysis, conducted using SPSS 16 software. The results of data analysis shows that: 1) There was a positive influence on teacher creativity in learning on student interest in learningduring the Covid-19 pandemic, based on the significance level of teacher creativity $\left(\mathrm{X}_{1}\right) 0.000<0.05$, and the value of t-count 3.805 that is greater than $\mathrm{t}$-table $1.984 ; 2)$ There is a significant effect of teacher learning interaction on student interest in learning during the Covid-19 pandemic, based on significance level of teacher interaction $\left(\mathrm{X}_{2}\right)$

$0.008<0.05$, and the t-count value of 2.719 greater than t-table 1.984;and 3) There is a significant effect of teacher creativity and interaction in learning on student learning interest during the Covid-19 pandemic with an F-count value of 15.213 that is higher than the value of F-table 3.09. Based on the results of the analysis, all Ha-s are accepted. Finally, it can be concluded that teacher creativity and interaction in learning have a significant effect both partially and simultaneously onstudent interest in the Covid-19 pandemic at State Vocational High School 2 Kuripan Academic Year 2020/2021.
\end{abstract}

Keywords: Teacher Creativity, Student Learning Interest

\section{PENDAHULUAN}

Kondisi pendidikan pada saat ini berada pada masa transisi dalam menyesuaikan keadaan yang sedang terjadi sejak Negara Indonesia menyatakan bahwa masuknya virus COVID-19 ini sebagai pandemi, aktifitas yang biasa dilakukan secara normal tiba-tiba semua aktifitas menjadi berubah, baik dari teknis persiapan hingga teknis pelaksanaanya dengan 
mempertimbangkan keselamatan dan kesehatan semua pelaku pendidikan.

Sekolah dituntut agar tetap melakukan pembelajaran dengan proses yang sudah diterapkan dalam pelaksanaan proses pembelajaran ditengah pandemi virus COVID-19 yang diatur dalam surat edaran Menteri Pendidikan dan Kebudayaan Republik Indonesia Nomor 4 Tahun 2020 Tanggal 24 Maret 2020 tentang pelaksanaan kebijakan pendidikan dalam masa darurat peneybaran coronavirus disease (COVID-19), didalamnya memberikan penekanan terhadap pembelajaran yang dilakukan secara daring yang dirasa memberikan tingkat resiko paling rendah untuk keselamatan di masa pandemi.

Menurut Riamin (2016: 236) minat belajar adalah salah satu faktor yang sangat penting untuk keberhasilan belajar yang dimiliki siswa, minat muncul dari dalam diri siswa itu sendiri apabila memiliki faktor dari luar yaitu bagaimana cara guru tersebut mengajar. Proses pembelajaran daring di masa pandemi sangat berpengaruh terhadap minat belajar siswa dikarenakan peran guru saat memberikan pembelajaran berbeda dari proses belajar secara tatap muka. Kreativitas guru merupakan upaya membangun berbagai terobosan yang memungkinkan bagi pemberdayaan dan penguatan bagi pengembangan bakat yang telah digali.

Menurut Sardiman (2012: 8) interaksi edukatif adalah komunikasi timbal balik antara pihak yang satu dengan pihak yang lain, sudah mengandung maksud-maksud tertentu, yakni untuk mencapai pengertian bersama yang kemudian untuk mencapai tujuan (dalam kegiatan belajar berarti untuk mencapai tujuan belajar). Kegiatan belajar mengajar di masa pandemi COVID-19 secara mendadak dijalankan menggunakan sistem belajar jarak jauh melalui daring.

Berdasarkan hasil observasi yang dilakukan oleh peneliti di SMKN 2 Kuripan memiliki sikap siswa yang tidak biasanya dimiliki siswa pada sekolah menengah ke atas (SMA). SMKN 2 Kuripan termasuk sekolah yang menerapkan pembelajaran secara daring di masa pandemi ini. Pada tanggal 15 Oktober 2020 peneliti melakukan pengamatan dan wawancara terhadap salah satu guru yang mengajar di sekolah tersebut, siswa di SMKN 2 Kuripan lebih cenderung kepada 1) sikap kritis, 2) rasa ingin tahu, 3) tingkah laku mereka yang labil, 4) rasa

bosan dan 5) kurangnya minat belajar yang selalu mereka ungkapkan melalu tindakan. Sejak ditetapkannya pembelajaran secara daring menjadi salah satu kendala yang membuat rendahnya minat belajar siswa disebabkan oleh siswa yang malas mengikuti pembelajaran yang telah dijadwalkan oleh pihak sekolah.

Berdasarkan uraian di atas diketahui bahwa permasalahan yang terjadi disaat pembelajaran jarak jauh yang dilakukan selama pandemi adalah 1) kreativitas guru dalam pembelajaran yang diberikan kurang bervariasi, kreatif, dan menyenangkan. Dapat dilihat dari guru yang memberikan pembelajaran terlalu menoton sehingga siswa merasa bosan saat mengikuti pembelajaran melalui media virtual seperti WhatsApp Group, Classroom, Google 
Meet dan Zoom, 2) siswa kurang memahami materi pembelajaran yang diberikan selama proses pembelajaran jarak jauh yang dilakukan secara daring, 3) kurangnya interaksi dan komunikasi antara guru dengan siswa yang terjadi selama prosesembelajaran dilihat banyaknya siswa yang mengikuti kegiatan belajar mengajar hanya beberapa siswa yang hadir di saat pembelajaran berlangsung, 5) kurangnya minat belajar siswa yang membuat siswa malas saat mengikuti pembelajaran daring, 6) kurangnya peran guru di saat pemberian pembelajaran membuat siswa cenderung menunggu perintah dari guru untuk mengerjakan tugas yang diberikan.

\section{METODE PENELITIAN}

Studi ini merupakan jenis penelitian kuantitatif dengan mengunakan rumusan masalah asosiatif untuk menanyakan pengaruh antara dua variabel atau lebih. Penelitian ini menggunakan metode deskriptif kuantitatif yaitu penelitian memaparkan informasi dalam bentuk angka-angka, kemudian dideskripsikan mengenai pengaruh kreativitas dan interkasi guru dalam pembelajaran terhadap minat belajar siswa di masa pandemi covid-19 di SMKN 2 Kuripan Tahun Pelajaran 2020/2021. Populasi dalam penelitian ini adalah seluruh siswa SMKN 2 Kuripan dengan jumlah 1308 siswa. Sampel penelitian 92,897 (dibulatkan menjadi 100 siswa) kemudian disebar secara acak/ random. Dalam penelitian ini sampel yang digunakan disebar secara acak dan proporsional kepada responden.

Teknik pengumpulan data dalam penelitian ini menggunakan angket dan dokumentasi. Jenis angket yang digunakan dalam penelitian ini adalah jenis angket tertutup. Angket tersebut digunakan untuk memperoleh data mengenai kreativitas guru, interaksi guru dalam pembelajaran dan minat belajar siswa di SMKN 2 Kuripan. Dokumentasi dalam penelitian ini digunakan untuk memperoleh data mengenai profil SMKN 2 Kuripan, dan daftar siswa.

Teknik analisis data dalam penelitian ini menggunakan uji prasyarat analisis data dan analisis regresi ganda. Uji prasyarat analisis data meliputi: uji normalitas, uji linearitas, uji kolonieritas, dan uji heteroskedastisitas.

\section{HASIL PENELITIAN DAN PEMBAHASAN}

Hasil analisis deskriptif menunjukkan bahwa minat belajar siswa di SMKN 2 Kuripan berada pada kategori cukup sebesar 71\%, kreativitas guru berada pada kategori baik sebesar $21 \%$, dan interaksi guru dalam pembelajaran berada pada kategori baik sebesar $47 \%$.

Berdasarkan hasil uji prasyarat analisis data diketahui bahwa uji normalitas menunjukkan nilai Asymp Sig tiap variabel lebih dari 0,05 maka data berdistribusi normal, sehingga prasyarat uji normalitas terpenuhi. Berdasarkan hasil uji linearitas menunjukkan bahwa nilai F sebesar 1,593 dengan sig 0,082, karena sig lebih dari 0,05 maka hubungan antara variabel kreativitas guru terhadap minat belajar bersifat linear. Dan nilai F sebesar 1,487 dengan sig 0,129, karena sig lebih dari 0,05 maka hubungan antara variabel interaksi guru terhadap minat belajar bersifat linear, sehingga prasyarat uji linearitas terpenuhi. Berdasarkan hasil uji kolinearitas menunjukkan bahwa nilai VIF sebesar 1,092, karena nilai tersebut kurang dari 4 maka tidak terjadi kolinearitas antara variabel kreativitas dan interkasi guru, sehingga prasyarat uji kolinearitas terpenuhi. Berdasarkan hasil uji heteroskedastisitas menunjukkan 
Volume 6 Nomor 1

April 2021

nilai sig kreativitas guru sebesar 0,319 dan nilai sig interkasi guru sebesar 0,841 lebih besar dari 
0,05 maka tidak terjadi heteroskedastisitas, sehingga persyaratan uji heteroskedastisitas terpenuhi. Dengan demikian prasyarat analisis regresi terpenuhi.

Analisis yang digunakan untuk menguji hipotesis dalam penelitian ini adalah dengan mensggunakan analisis regresi ganda.

Berdasarkan persamaan regresi berganda sebagai berikut: $\mathrm{Y}=5,541+0,387 \mathrm{X} 1+$ 0,314 X2. Hasil koefisien determinasi R2 sebesar 0,225. Nilai R2 tersebut menunjukkan derajad korelasi antara variabel kreativitas guru dan interaksi guru dalam pembelajaran terhadap minat belajar. Nilai R2 menunjukkan angka koefisien determinasi, yang artinya variansi dalam minat belajar ekonomi dapat dijelaskan oleh interaksi guru dengan siswa dan lingkungan belajar sebesar 22,5\% sisanya 77,5\% berasal dari variabel lain.

Berdasarkan hasil analisis uji parsial (uji t) diketahui variabel kreativitas guru ( $\left.\mathrm{X}_{1}\right)$ berpengaruh secara positif dan signifikan terhadap minat belajar siswa. Hal ini dapat dilihat dari taraf signifikansi kreativitas guru $\left(\mathrm{X}_{1}\right)$ 0,000 < 0.05, dan diketahui nilai thitung 3,805 lebih besar dari tabel $1.984(3,805>1,984)$. Berdasarkan hasil ini, maka hipotesis nihil (Ho) ditolak, sedangkan hipotesis alternatif (Ha) diterima, atau dengan kata lain kreativitas guru berpengaruh signifikan terhadap minat belajar siswa, sehingga hipotesis pertama diterima. Sedangkan hasil analisis uji parsial (uji t) diketahui variabel interaksi guru $\left(\mathrm{X}_{2}\right)$ berpengaruh secara positif dan signifikan terhadap minat belajar siswa. Hal ini dapat dilihat dari taraf signifikansi interaksi guru $\left(\mathrm{X}_{2}\right) 0,008<0.05$, dan diketahui nilai thitung 2,719 lebih besar dari tabel $1.984(2,719>1,984)$. Berdasarkan hasil ini, maka hipotesis nihil (Ho) ditolak, sedangkan hipotesis alternatif (Ha) diterima, atau dengan kata lain kreativitas guru berpengaruh signifikan terhadap minat belajar siswa, sehingga hipotesis kedua diterima.

Berdasarkan hasil analisis uji simultan (uji $F$ ) diketahui nilai $F_{\text {hitung }}$ sebesar 15,213 dengan nilai $F_{\text {tabel }}$ adalah 3,09 sehingga nilai $F_{\text {hitung }}>F_{\text {tabel }}$ atau 15,213> 3,09 dengan taraf signifikansi $0,000<0,05$. Berdasakan hasil ini maka hipotesis nihil (Ho) ditolak, sedangkan hipotesis alternatif (Ha) diterima, atau dengan kata lain kreativitas dan interaksi guru berpengaruh signifikan terhadap minat belajar siswa, sehingga hipotesis ketiga diterima.

\section{Pengaruh kreativitas guru terhadap minat belajar siswa}

Berdasarkan hasil angket menunjukkan nilai kreativitas guru dalam pembelajaran tergolong cukup baik 76\%, dimana siswa menilai bahwa kreativitas guru dalam pembelajaran selama daring mampu menciptakan pembelajaran secara kreatif sehingga siswa lebih tertarik dan berpartisipasi untuk mengikuti pembelajaran, guru dapat menggunakan beberapa metode atau variasi dalam menerangkan materi pembelajaran secara daring, sehingga siswa tidak merasakan bosan saat pembelajaran berlangsung. Siswa lebih bersemangat ketika guru mengajar dengan menggunakan bermacam-macam media yang membuat siswa cepat menyerap materi pembelajaran yang diberikan secara daring. Hasil tersebut sesuai dengan teori bahwa kreativitas guru dalam pembelajaran memberikan pengaruh terhadap minat belajar siswa dan mendukung penelitian sebelumnya yang telah dilakukan oleh Sari (2017) dan Noviantari (2017) bahwa kreativitas guru dalam pembelajaran berpengaruh terhadap minat belajar siswa. 


\section{Pengaruh interaksi guru terhadap minat belajar siswa}

Berdasarkan hasil angket yang telah diisi siswa di SMKN 2 Kuripan, dengan pesepsi siswa terhadap interkasi guru dalam pembelajaran bahwa kategori yang diperoleh cukup baik $49 \%$. Siswa memberikan penilaian bahwa guru mampu menciptakan suasana yang menyenangkan dalam kegatan belajar mengajar secara daring dan menyuruh siswa untuk selalu ikut berdiskusi serta memberikan kesempatan siswa untuk bertanya apabila masih ada yang kurang paham terhadap materi yang pembelajaran yang diajarkan walaupun pembelajaran dilakukan secara daring. Guru juga selalu mendampingi dan membimbing siswa jika ada yang kurang paham tentang materi pembelajaran yang diajarkan. Bahkan guru membangun komunikasi atau interaksi yang baik dengan siswa, guru juga membantu siswa jika ada yang mengalami kesulitan dalam mengerjakan tugas selama pembelajaran yang dilakukan secara daring dimasa pandemi ini. Hasil tersebut sesuai dengan teori bahwa interaksi guru dalam pembelajaran memberikan pengaruh terhadap minat belajar siswa dan mendukung penelitian sebelumnya yang telah dilakukan oleh Ramadhani (2018) bahwa interaksi guru dalam pembelajaran berpengaruh terhadap minat belajar siswa.

\section{SIMPULAN}

Berdasarkan hasil analisis data dapat disimpulkan sebagai berikut:

1. Dari hasil analisis terdapat pengaruh positif kreativitas guru terhadap minat belajar siswa di SMKN 2 Kuripan. Hal ini dibuktikan dengan nilai signifikan kreativitas guru $\left(\mathrm{X}_{1}\right) 0,000<$ 0.05, dan diketahui nilai thitung 3,805 lebih besar dari tabel 1.984. Berdasarkan hasil ini, maka H1 diterima, atau dengan kata lain hipotesis alternatif (Ha) diterima. Hasil ini menggambarkan semakin baik kreativitas guru dalam pembelajaran secara daring maka semakin baik minat belajar siswa selama proses pembelajaran secara daring di masa pandemi Covid-19.

2. Dari hasil analisis terdapat pengaruh positif interkasi guru terhadap minat belajar siswa di masa pandemi Covid-19 di SMKN 2 Kuripan. Hal ini dapat dibuktikan dengan nilai signifikan kreativitas guru $\left(\mathrm{X}_{1}\right) 0,008<0.05$, dan diketahui nilai thitung 2,719 lebih besar dari $t_{\text {tabel }}$ 1,984. Berdasarkan hasil ini, maka $\mathrm{H} 2$ diterima, atau dengan kata lain hipotesis alternatif (Ha) diterima. Hasil ini menggambarkan semakin baik interaksi guru dalam pembelajaran maka semakin baik minat belajar siswa selama proses pembelajaran secara daring di masa pandemi Covid-19.

3. Berdasarkan hasil analisis terdapat pengaruh positif kreativitas dan interkasi guru dalam pembelajaran terhadap minat belajar siswa di masa pandemi Covid-19 di SMKN 2 Kuripan. Hal ini dibuktikan dengan nilai uji simulta (uji F) nilai $F_{\text {hitung }}$ sebesar 15,213 dengan nilai $F_{\text {tabel }}$ adalah 3,09 sehingga nilai $F_{\text {hitung }}>F_{\text {tabel }}$ atau dengan tingkat signifikan 0,000<0,05 yang berarti Ho ditolak dan Ha diterima. Dengan demikian dapat ditarik kesimpulan bahwa kreativitas dan interaksi guru dalam pembelajaran berpengaruh terhadap minat belajar siswa di masa pandemi Covid-19 di SMKN 2 Kuripan Tahun Pelajaran 2020/2021. 


\section{REFERENSI}

Edy, Syahputra. 2020. Snowball Throwing Tingkatan Minat Belajar dan Hasil Belajar. Sukabumi: Haura Publishing.

Ramadhani, Diantyastuti. 2018. Pengaruh Interaksi Guru Dengan Siswa Dan Lingkungan Belajar Terhadap Minat Belajar Ekonomi Siswa Kelas Xi Iis SMAN I Wates. Skripsi: Fakultas Ekonomi Universitas Negeri Yogyakarta. Yogyakarta.

Riamin. 2016. Menumbuhkan Minat Belajar Siswa dalam Pembelajaran. https://www.kompasiana.com/riamin/57ec6323697738d1a3e38b6/menumbuhkan-minatbelajar-siswa-dalam-pembelajaran. Diakses pada tanggal 8 januari 2021 pukul 20:19 WITA.

Sardiman. 2012. Interkasi dan Motivasi Belajar Mengajar. Jakarta: Raja Grafindo Pesada.

Slameto. 2007. Belajar dan Faktor-faktor yang Mempengaruhinya. Jakarta: Rineka Cipta.

Syahputra, E. 2020. Snowball Throwing Tingkatan Minat dan Hasil Belajar. Sukabumi: Haura Publishing.

Talajan, Guntur. 2012. Menumbuhkan Kreativitas \& Djamarah, Bahri. S. 2010. Guru dan Anak Didik Dalam Interaksi Edukatif. Edisi Revisi. Jakarta: PT Rineka Cipta 